\title{
Sensitivity of the sorghum yield to individual changes in climate parameters: modelling based approach
}

\author{
Marine Cirino Grossi ( $\left.{ }^{(}\right)$; Flávio Justino $\left({ }^{2}\right)$; Rafael de Ávila Rodrigues ( ${ }^{3 *}$ ); \\ Camilo Lelis Teixeira Andrade $\left({ }^{4}\right)$ \\ (') Instituto Federal do Norte de Minas Gerais (IFNMG), Rod. MG 202 km 407, 38680-000 Arinos (MG), Brasil. \\ (2) Universidade Federal de Viçosa (UFV), Departamento de Engenharia Agrícola, Av. Peter Henry Rolfs, s/n, \\ 36570-900 Viçosa (MG), Brasil. \\ (3) Universidade Federal de Goiás (UFG), Regional Catalão, Av. Dr. Lamartine P. Avelar, 1120, 75704-020 Catalão (GO), Brasil. \\ (4) Embrapa Milho e Sorgo, Rod. MG 424 km 45, 35701-970 Sete Lagoas (MG), Brasil. \\ (*) Corresponding author: rafael.avila.roodrigues@gmail.com
}

Received: Nov. 20, 2014; Accepted: Mar. 16, 2015

\begin{abstract}
Based on sensitivity analyses the effect of changing in climate on sorghum has been investigated. This has been achieved by conducting crop modeling experiments carried out with weather observations and output of global climate models. As can be anticipated results demonstrated that the sorghum yield is more sensitive to rainfall, solar radiation and $\mathrm{CO}_{2}$ concentration. However, the increase in $\mathrm{CO}_{2}$ concentration has a positive effect on yield in years that the crop is submitted to water stress. This effect is extremely reduced under well watered conditions and therefore is subject to the climate inter-annual variability. Accumulated solar radiation along the sorghum cycle below $1900 \mathrm{MJ} \mathrm{m}^{-2}$ has also been shown to reduce the yield. Compared to other weather variables the sorghum yield is less sensitive to changes in relative humidity. In this sense, changes in stomatal closure and therefore photosyntesis is not highly dependent on water vapor pressure. These finds can be applied for both climate observations and global models output.
\end{abstract}

Key words: climate change, crop models, sensitivity analyses, $\mathrm{CO}_{2}$ concentration, productivity.

\section{INTRODUCTION}

Water shortage is a limiting factor to profitable crop productivity in particular for maize, common beans and other subsistence crops (Teixeira \& Bassoi, 2009). The productivity of sorghum, and of other crops may be altered as a result of global climate change. However, Conley et al. (2001) argued that increasing concentration of carbon dioxide $\left(\mathrm{CO}_{2}\right)$ in rainfed conditions, can increase the sorghum productivity in the future due to increased water use efficiency (WUE).

To analyze the crop response to future climate change scenarios, outputs of global circulation models (GCM) have been utilized as input data to crop models (Tubiello et al., 2000). Moreover, the use of calibrated and validated crop model can replace experiments traditionally performed in the field (Matthews et al., 2000). According to Saltelli et al. (2004), sensitivity analysis is the study of how the variation in the output of a model can be attributed qualitatively or quantitatively to variations of a model parameters or input data.

In semi-arid regions current weather conditions are in general adverse to crop production. Family farmers rely on rainfed agriculture and are therefore affected by changes in climate/weather, and future climate changes can substantially reduce the productivity (Tubiello et al., 2000). Srivastava et al. (2010) indicated a decrease in productivity in India in two of the three regions studied. Chipanshi et al. (2003) has also found reduction of the sorghum productivity. However, Carbone et al. (2003) found an increase in productivity by up to $40 \%$ in the southeast region of the USA, by considering the $\mathrm{CO}_{2}$ fertilization effect, adaptation strategies and shifting cultivars. Costa et al. (2009) argued that adverse future climate conditions on crops can be attenuated by the highly efficient $\mathrm{CO}_{2}$ fertilization effect and suitable crop management.

It should be noted that few studies have been conducted for the tropical semi-arid regions focusing on modeling the sorghum productivity under current and future climate conditions (e.g. Grossi et al., 2013). Therefore, the present study aims to evaluating the productivity of sorghum, considering current and future climate conditions based on observations and on Global Climate Models (GCMs) output. 


\section{MATERIALS AND METHODS}

\section{Experimental setup and modeling design}

Modeling experiments focusing on the productivity of sorghum were performed taking into account the conditions of soil and climate of the municipality of Janaúba (Lat.15, $80^{\circ} \mathrm{S}$, Long. $43.30^{\circ} \mathrm{W}$, Elevation $516 \mathrm{~m}$ ). This city is located in the northern part of Minas Gerais State, Brazil, and is the second largest city of northern Minas Gerais. The annually averaged total rainfall is $774 \mathrm{~mm}$ based on climatology (1982-2009) obtained from the Brazilian Institute of Meteorology (INMET, Figure 1a). The highest average daily solar radiation of $24 \mathrm{MJm}^{-2}$ day $^{-1}$ occurs in February and the lowest of $17 \mathrm{MJm}^{-2} \mathrm{day}^{-1}$ is registered in June. Records of monthly average air temperatures (Figure 1b), show that in Janaúba maximum temperatures varies between $29^{\circ} \mathrm{C}$ in July and $33^{\circ} \mathrm{C}$ in October.

The modeling experiments have been conducted by using soil conditions as proposed by the Embrapa Maize and Sorghum experimental station located nearby Janaúba, which is classified as Haplustox. Some of its physical and chemical characteristics are presented in table 1 .

In DSSAT the soil is represented by a one-dimensional profile, which is horizontally homogeneous, and has several vertical layers (Jones et al., 2003). It is considered a depth of $1.90 \mathrm{~m}$ with the most roots concentrated in a depth of 1.40 as observed in the field. The crop root distribution is represented by the root growth factor that varies from 0 to 1 . The root growth factor values are stored in the soil profile file. For the present study the depth of the sorghum rooting system was set to $1.40 \mathrm{~m}$. Details of the experimental design and field trials can be found in Grossi et al. (2013).

\section{Description of the CSM-CERES-Sorghum model}

The models of the CERES (Crop Estimation through Resource and Environment Synthesis) are employed to estimate the productivity of grains such as maize, rice, wheat, barley, millet and sorghum. The CSM-CERES-Sorghum is part of the modular system called Crop System Model (CSM) present in the Decision Support System for Agrotechnology Transfer (DSSAT) version 4.5 (Jones et al., 2003). It is based on the model CERES-Sorghum (Alagarswamy et al., 1988) that describes the production and partitioning of the plant biomass and its phenology. The model interconnects the processes of environmental variations and plant management (Carbone et al., 2003). Indeed, crop modeling allows for investigating the impact of individual weather variables on the growth and development of the plant, by performing sensitivity analysis.

\section{Climate Timeseries}

The DSSAT model has additional modules to include soil characteristics (e.g. carbon, nitrogen, water) and environmental conditions (e.g. weather, soil-plant-atmosphere). In the present study, the Penman-Monteith method (FAO-56) is used to calculate the potential evapotranspiration. Thus, meteorological variables used as daily input data are precipitation
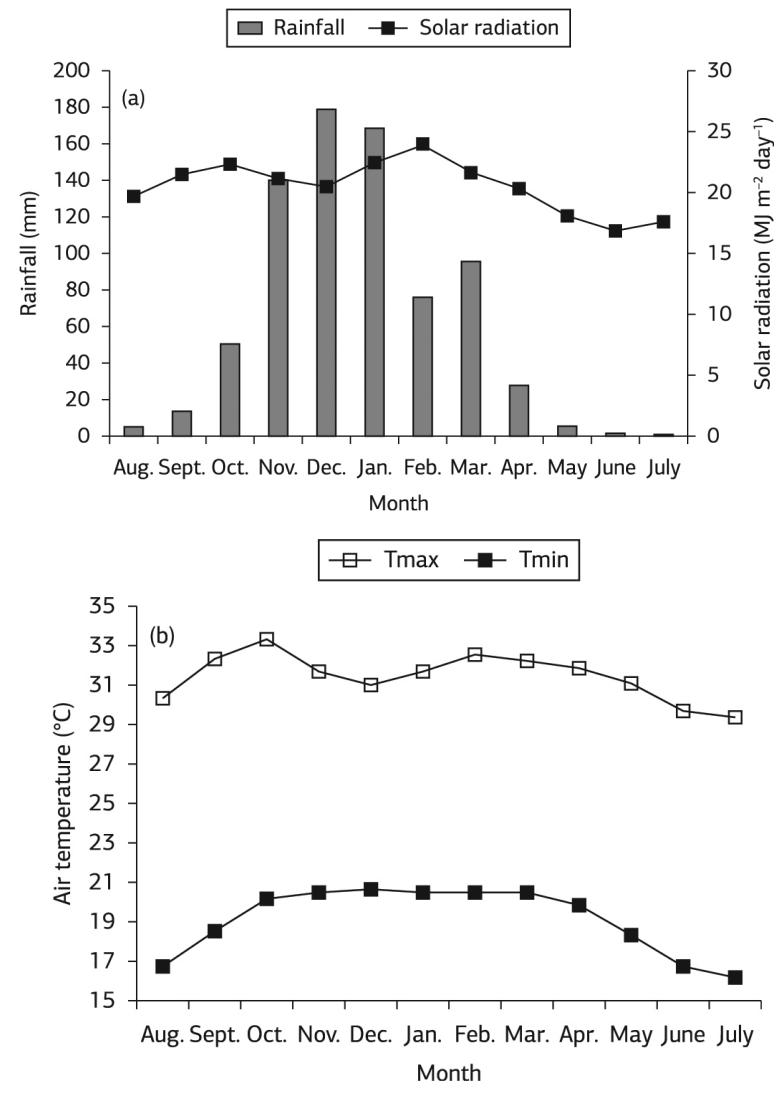

Figure 1. Monthly climatology of rainfall and maximum and minimum temperatures based on INMET dataset.

Table 1. Soil properties for the experiments conducted in Janaúba and Sete Lagoas, MG, Brazil. Average values of soil profiles. This table is based on Grossi et al. (2013)

\begin{tabular}{|ccc|}
\hline Physical properties & Unit & Janaúba \\
\hline Sand & $(\%)$ & 42.43 \\
Silt & $(\%)$ & 22.71 \\
\hline Clay & $(\%)$ & 34.86 \\
\hline Bulk density & $\left({\left.\mathrm{kg} 10^{3} \mathrm{~m}^{-3}\right)}^{-3}\right.$ & 1.54 \\
\hline Upper limit, drained & $\left(\mathrm{m}^{3} \mathrm{~m}^{-3}\right)$ & 0.25 \\
\hline Lower limit & $\left(\mathrm{m}^{3} \mathrm{~m}^{-3}\right)$ & 0.12 \\
\hline Upper limit, saturated & $\left(\mathrm{m}^{3} \mathrm{~m}^{-3}\right)$ & 0.37 \\
\hline Chemical properties & & Janaúba \\
\hline pH in water & - & 7.06 \\
\hline Organic matter & $\left(\mathrm{dag} \mathrm{Kg}^{-1}\right)$ & 0.65 \\
\hline Nitrate & $\left(\mathrm{mg} \mathrm{Kg}^{-1}\right)$ & - \\
\hline Ammonium & $\left(\mathrm{mg} \mathrm{Kg}^{-1}\right)$ & - \\
\hline Total nitrogen & $(\%)$ & 0.07 \\
\hline Textural Class & & Medium \\
\hline
\end{tabular}


$\left(\mathrm{mm}\right.$ day $\left.^{-1}\right)$, solar radiation $\left(\mathrm{MJ} \mathrm{m}^{2}\right.$ day $\left.^{-1}\right)$, maximum and minimum air temperature $\left({ }^{\circ} \mathrm{C}\right)$, relative humidity $(\%)$ and wind speed $\left(\mathrm{m} \mathrm{s}^{-1}\right)$. For the INMET data, the values of global solar radiation were estimated from the number of hours of sunshine and solar radiation at the top of the atmosphere using the coefficients $\mathrm{a}=0.25$ and $\mathrm{b}=0.50$ recommended by Allen et al. (1998) in the Angstrom equation.

In addition to observed data from INMET, three databases obtained through global circulation climate models, namely ECHAM5/MPI-OM, CCCma CGCM3.1 (T63) and GFDL-CM2.1 have been used primarily to simulate the effect of future climate conditions on sorghum yield. The coupled model ECHAM5/MPI-OM used in this study has a spatial resolution of $1.9^{\circ}$ latitude and longitude, with 31 vertical pressure levels. The Coupled Global Climate Model (CGCM) 3.1 is the third version generated by the Canadian Centre for Climate Modelling and Analysis (CCCma). It has a surface grid with spatial resolution of approximately $2.8^{\circ} \times 2.8^{\circ}$ latitude and longitude and 31 vertical levels.

The GFDL coupled model run under a resolution of $2^{\circ}$ latitude and $2.5^{\circ}$ longitude and 24 vertical levels. Detailed information on the global circulation climate models were described elsewere (Jungclaus et al., 2006; Flato \& Hibler, 1992; Flato \& Boer, 2001; Kim et al., 2002, 2003; Delworth et al., 2006).

Sorghum grain yields, on a dry matter basis, have been calculated for the period of 1982 to 1999 by using the INMET's weather time series. This approach is here in identified as present day (PD). The impact of climate change in the crop yields has been computed for the 2047 to 2064 interval, here in identified as Greenhouse Warming experiment $(\mathrm{GW})$. For $\mathrm{PD}$, the $\mathrm{CO}_{2}$ forcing was based on concentrations of greenhouse gases and anthropogenic aerosols observed at Mauna Loa (Hawaii, USA).

For GW, the $\mathrm{CO}_{2}$ concentrations followed the SRES A1B scenario (Special Report on Emissions Scenarios) described by Nakicenovic et al. (2000). $\mathrm{CO}_{2}$ concentrations were used as input data to the model CSM-CERES-Sorghum, so that the sorghum crop response to $\mathrm{CO}_{2}$ fertilization could be simulated. In this simulation the $\mathrm{CO}_{2}$ concentration is between 420 and 500 ppm.

\section{Crop genetic coefficients and seasonal analyses}

The calibration was performed from the average data collected in two field experiments conducted in Sete Lagoas (Minas Gerais). In table 2 are presented the averages of the repetitions of field experiments used to guide the process of calibration coefficients, as well as the standard deviation of the repetitions. The values of the variables related to the crop phenology are presented in days after sowing (DAS), while growth and yield variables refer to the dry weight ( $0 \%$ humidity) in the final harvest.

Table 2 are the values of percentage of deviance (PD), as well as the Willmott agreement index (d) and FSM. Positive values of PD indicate overestimate negative values indicate while under-estimating the model in relation to the observed data.

It is possible to notice that there was a good fit of the data. The model was able to simulate the growth and development of BRS 310 variety of exact and precise way. This can be proven through the high values of the coefficients $\mathrm{d}$ and FSM, equal to 0.99 , in both plantations.

DSSAT crop models require parameterization of the genetic coefficients, which are specific for each cultivar to properly describe the processes related to growth, development and grain production. The coefficients used in this study have been previously adjusted and evaluated for the cultivar BRS 310 , by using data from field trials carried out in 2 cities namely Sete Lagoas and Rio Verde in the central part of Brazil (Goiás State). These coefficients have been presented by Grossi et al. (2013) and for brevity they are not shown here.

The management practices considered in the simulations consisted of row spacing of $0.70 \mathrm{~m}$ and 18 plants $\mathrm{m}^{-2}$. Nitrogen rates were $32 \mathrm{~kg} \mathrm{ha}^{-1}$ of nitrogen $(\mathrm{N})$ per at sowing and $60 \mathrm{~kg} \mathrm{ha}^{-1}$ and $45 \mathrm{~kg} \mathrm{ha}^{-1}$, as urea, side-dressed 30 and 45 days after sowing, respectively. The most appropriated

Table 2. Observed and simulated development data used for calibration of cultivar -specific coefficients of the hybrid BRS 310

\begin{tabular}{|c|c|c|c|c|c|c|c|}
\hline \multirow{2}{*}{ Experiment } & \multirow{2}{*}{ Stage } & \multicolumn{2}{|c|}{ Observed } & \multirow{2}{*}{ Simulated } & \multirow{2}{*}{ PDc (\%) } & \multirow{2}{*}{ dd } & \multirow{2}{*}{ MEFe } \\
\hline & & S.D.b & Mean & & & & \\
\hline \multirow{6}{*}{ SL0902 } & Emergence (DASa) & 0.0 & 7 & 6 & -14.3 & \multirow{6}{*}{0.99} & \multirow{6}{*}{0.99} \\
\hline & Panicle initiation (DAS) & 0.0 & 36 & 37 & 2.8 & & \\
\hline & Anthesis (DAS) & 1.2 & 71 & 70 & -1.4 & & \\
\hline & Physiological maturity (DAS) & 1.9 & 105 & 109 & 3.8 & & \\
\hline & Grain yield $\left(\mathrm{kg} \mathrm{ha}^{-1}\right)$ & 406.1 & 6085 & 6093 & 0.1 & & \\
\hline & Aboveground dry biomass at maturity $\left(\mathrm{kg} \mathrm{ha}^{-1}\right)$ & 2309.8 & 16886 & 15947 & -5.6 & & \\
\hline \multirow{4}{*}{ SL1001 } & Emergence (DAS) & 0.0 & 4 & 6 & 50.0 & \multirow{4}{*}{0.99} & \multirow{4}{*}{0.99} \\
\hline & Panicle initiation (DAS) & 0.0 & 32 & 32 & 0.0 & & \\
\hline & Anthesis (DAS) & 1.0 & 67 & 64 & -4.5 & & \\
\hline & Physiological maturity (DAS) & 1.5 & 113 & 112 & -0.9 & & \\
\hline
\end{tabular}

${ }^{\mathrm{a}}$ Days After Sowing. ${ }^{\mathrm{b}}$ Standart Deviation (variable unit). ${ }^{\mathrm{c}}$ Percentage deviation (\%). ${ }^{\mathrm{d} A g r e e m e n t ~ i n d e x ~ W i l l m o t t . ~}{ }^{\mathrm{e}}$ Modelling Eficiency. 
date for sowing sorghum in Janaúba is previously determined by Grossi et al. (2013), and are used in the present study (Table 2). Therefore, sensitivity analyses were performed solely for that maximum yield date which varies depending on climate observation and the GCMs datasets.

\section{Sensitivity analysis}

Sensitivity analyses were conducted to evaluate the CSM-CERES-Sorghum response to variation in meteorological elements and in distinct concentrations of $\mathrm{CO}_{2}$. The analyses considering observed data were performed in four years that have shown different yield levels: (1) a year with low productivity (2) two years with intermediate productivity and, (3) a year with higher productivity.

To determine the interval of changes for each variable in the sensitive analyses, its maximum and minimum values within the four selected years have been taken. Thus, for relative humidity and solar radiation it was considered a reduction and increment of $20 \%$ in the daily values. For precipitation, the variation was $\pm 40 \%$, and for the wind speed $\pm 50 \%$. Exception to this applies for the $\mathrm{CO}_{2}$ and temperature. For the former, we adopted a variation of $\pm 50 \%$ with initial value of $380 \mathrm{ppm}$ aiming to represent both concentrations observed in the past and those that are likely to be present in the future. It should be stressed that changes in $\mathrm{CO}_{2}$ maintaining the temperature unchanged is questionable because in nature they change in phase. Nevertheless, this kind of experiment allows for the investigation of the individual fertilization effect on sorghum yield (Table 3 ).

To determine the interval of the climatic variables admitted that the distributions of variables per cycle are approximately normal. It is known that for a normal distribution, $99.73 \%$ of the occurrences are within 3 standard deviations from the average. Thus, the percentages of variation were determined

Table 3. Range of Study of variables

\begin{tabular}{lcccc|} 
& $\begin{array}{c}\text { Rainfall } \\
(\mathbf{m m} \\
\left.\mathbf{c y c l e}^{-1}\right)\end{array}$ & $\begin{array}{c}\text { Solar } \\
\text { radiation } \\
\left(\mathbf{M J ~ m}^{-2} \mathbf{c y c l e}^{-1}\right)\end{array}$ & $\begin{array}{c}\text { Relative } \\
\text { Humidity } \\
(\%)\end{array}$ & $\begin{array}{c}\text { Wind } \\
\text { Speed } \\
\left(\mathbf{m ~ s}^{-1}\right)\end{array}$ \\
\hline $\begin{array}{l}\text { Variation } \\
\text { Minimun }\end{array}$ & $40 \%$ & $20 \%$ & $20 \%$ & $50 \%$ \\
$\begin{array}{l}\text { Value } \\
\text { Maximum } \\
\text { Value }\end{array}$ & 245.82 & 1489.68 & 50.008 & 0.36 \\
\hline
\end{tabular}

in such a way that the meteorological variables were studied in this range.

Sensitivity experiments including changes in temperature are implemented by modifications in the daily thermal amplitude, but keeping the daily mean temperature constant. It should be noted that the analyses must be done in simulations with the same cycle duration. Variations in productivity caused by changes in the input variables were calculated as follows:

Var $=\left(\frac{P r-P r_{i}}{P r_{i}}\right) \times 100$

Where

Var: is the variation in grain yield caused by the variation of daily rainfall, solar radiation, wind speed, relative humidity or $\mathrm{CO}_{2}$, in \%;

$\operatorname{Pr}_{\mathrm{i}}$ : is the simulated yield obtained by using observed data in $\mathrm{kg} \mathrm{ha}^{-1}$.

Pr is the yield due to changes in the input variables, $\mathrm{kg} \mathrm{ha}^{-1}$.

\section{RESULTS AND DISCUSSION}

\section{Variability of the simulated yields}

The four values of grain yield chosen for the sensitivity analysis are in the range of 1,758 and $6,353 \mathrm{~kg} \mathrm{ha}^{-1}$ for years 1993, 2001, 2007 and 2008 (Table 4). One can note that the maximum and minimum temperature varied by only $1{ }^{\circ} \mathrm{C}$ among the analyzed years. For relative humidity, solar radiation, wind speed and precipitation, the differences between the 2007 season (minimum yield) and 2001 (maximum yield) were 17.5\%, 22.6\%, 57.0\% and $133.0 \%$, respectively. Since no changes occurred in the crop management, it is reasonable to assume that the weather conditions were crucial to variations in the sorghum yields.

In DSSAT, photosynthesis and dry matter production is affected by the plant water stress, which depends on soil-water and precipitation. The water stress index is determined by the actual and potential crop evapotranspiration. If this ratio is lower than 1.0, it indicates that the stomatal conductance should be reduced to prevent desiccation of the plant. This assumption is used to reduce photosynthesis in proportion to transpiration (Jones et al., 2003). Figure 2 shows that in

Table 4. Meteorological variables values during the sorghum cycle based on INMET dataset

\begin{tabular}{|c|c|c|c|c|c|c|c|c|}
\hline $\begin{array}{c}\text { Yield } \\
\left(\mathbf{k g ~ h a}^{-1}\right)\end{array}$ & Year & $\begin{array}{l}\text { Cycle } \\
\text { length } \\
\text { (day) }\end{array}$ & $\begin{array}{l}\text { Accum. } \\
\text { Precipitation } \\
\left(\mathrm{mm} \text { cycle }^{-1}\right)\end{array}$ & $\operatorname{Tmax}\left({ }^{\circ} \mathrm{C}\right)$ & $\operatorname{Tmin}\left({ }^{\circ} \mathrm{C}\right)$ & $\begin{array}{l}\text { Accum. Solar } \\
\text { radiation } \\
\left(\mathrm{MJ} \mathrm{m}^{-2} \text { ciclo-1) }^{-1}\right.\end{array}$ & $\begin{array}{l}\text { Mean } \\
\text { Wind } \\
\text { speed } \\
\left(\mathrm{m} \mathrm{s}^{-1}\right)\end{array}$ & $\begin{array}{c}\text { Mean } \\
\text { relative } \\
\text { humidity } \\
(\%)\end{array}$ \\
\hline 1758 & 2007 & 101 & 431 & 32 & 21 & 2251 & 0.7 & 63 \\
\hline 3635 & 1993 & 99 & 410 & 32 & 22 & 1862 & 1.1 & 70 \\
\hline 4679 & 2008 & 104 & 526 & 31 & 21 & 2182 & 0.9 & 67 \\
\hline
\end{tabular}


2007, water stress was observed in three of the five phases in which the crop cycle was divided. Despite having a total accumulated rainfall depth higher than that observed in 1993, sorghum yield was lower in 2007. The year 2001, which delivered the highest productivity, water stress is not observed throughout the crop cycle (Figure 2). In 2008 and 1993 water stress occurs during the grain filling stage a critical periods regarding the effect of water stress on sorghum productivity.

Results based on the sensitivity analyses (Figure 3a), demonstrated that variations in precipitation are in phase and positively correlated with variation of productivity. It is important to note that in 2007, whose precipitation was $431 \mathrm{~mm}$, changes in yield due to changes in precipitation is higher as compared to the other years (Figure $3 \mathrm{a}$ ). Increase or reduction of rainfall in the range of $\pm 40 \%$ resulted in fluctuation in yield from $-50 \%$ to $+54 \%$. On the other hand, in 2001 whose accumulated precipitation is considerably higher and well distributed (Figure 2), the sorghum yield is hardly affected by changes in rainfall.

In 1993 (Figure 3b) and 2001 (Figure 3d) our results show that changes in solar radiation lead to the largest yield variation. A $20 \%$ increment in the solar radiation resulted in a 30\% increase in yield. This effect is however no linear in the sense that $10 \%$ reduction of radiation is associated with a $35 \%$ drop in yield.

In 2007 (Figure 3a) the yield response curve to solar radiation shows a different shape. Reduction in radiation by up to $18 \%$ leads to increased productivity. However, additional reduction in solar radiation led to substantial yield drop. In 2008 (Figure 3c) the crop response to changes in radiation is weak as compared to the other years. This non-linear effect of radiation on the productivity indicates that the yield response is associated also with the interaction among the other variables. This turns out that evaluation for future crop response to climate changes is complicated, as discussed later.

The changes in productivity associated with variations in relativity humidity and wind are smaller as compared to changes in precipitation and radiation. This was not

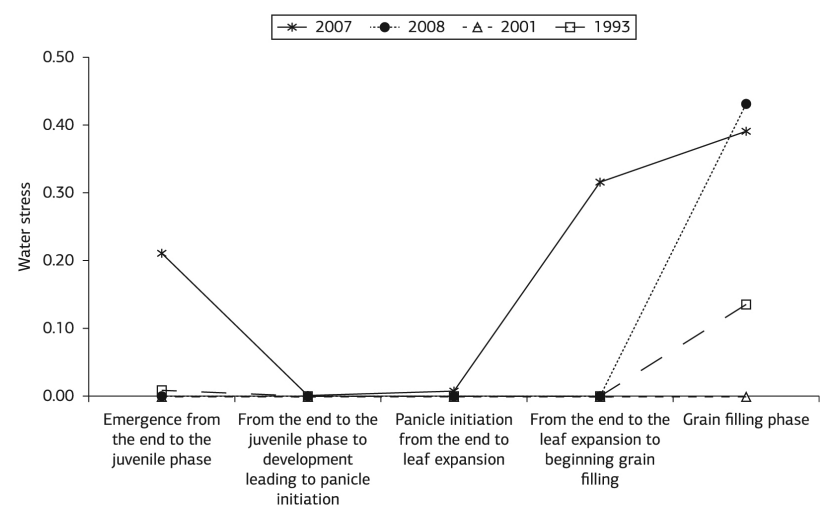

Figure 2. Simulated water stress in different phases of the sorghum cycle. anticipated because the relativity humidity and surface wind play an important role on crop evapotranspiration. The wind speed had similar behavior in years 2007, 1993 and 2008 showing a negative relationship with productivity (e.g. higher winds/lower productivity). In 2001, when rainfall was high $(955 \mathrm{~mm})$ the effect of wind speed $(50 \%$ increase) was practically absent, showing a slight reduction in productivity due to small changes in the water balance. The effect of relative humidity on yield has demonstrated an opposite pattern as compared with that observed for wind speed.

It is interesting to note, the remarkable effect of $\mathrm{CO}_{2}$ on sorghum yields especially when it faces water stress conditions. It was evident that the crop response to $\mathrm{CO}_{2}$ is related to the amount of precipitation accumulated during the cycle (Figure 3). For instance, increasing $\mathrm{CO}_{2}$ levels under mild water stress conditions does not result in increased productivity, such as in 2001 (Figure 3d). However, for dryer years the crop dependence to $\mathrm{CO}_{2}$ is higher. The $\mathrm{CO}_{2}$ effect on the crop yield is stronger for concentration below 270 ppm or less, a value close to the observed prior to the Industrial Revolution. For the year 2001, an increase in $50 \%$ of the atmospheric $\mathrm{CO}_{2}$ concentration (ca. $570 \mathrm{ppm}$ ) is responsible for only $2 \%$ increase in productivity.

In general the results discussed above insofar the link between the $\mathrm{CO}_{2}$ concentration and sorghum yield is concerned, agree with those obtained by Conley et al. (2001) in a FACE (Free-air $\mathrm{CO}_{2}$ Enrichment) experiments. They found enhanced productivity of sorghum under water deficit conditions. One can argue, moreover, that when water conditions is potential (minor stress), the effect of adding $\mathrm{CO}_{2}$ may be neglected, but under drought stress conditions it contributes to increase the sorghum yield.

\section{Effect of temperature}

The relationship between the daily thermal amplitude (difference between the daily maximum and minimum temperatures) and productivity is shown in figure 4. It should be noted that changes in the temperature amplitude was only due to reduction in the minimum temperature. It was observed that in 2001 changes in the temperature amplitude hardly affected sorghum productivity. For this year, changes in the yield occurred only when differences between the daily maximum and minimum temperatures exceeded $12{ }^{\circ} \mathrm{C}$.

For the years 1993, 2007 and 2008 the initial pattern was similar, showing a downward trend in productivity as result of increased thermal amplitude. However, for amplitudes higher than $13{ }^{\circ} \mathrm{C}$ a positive trend is observed in the year 1993 (Figure 4).

The relationship between the amplitude changes and productivity is not straightforward because it depends on the crop water stress. This is exemplified by the crop 


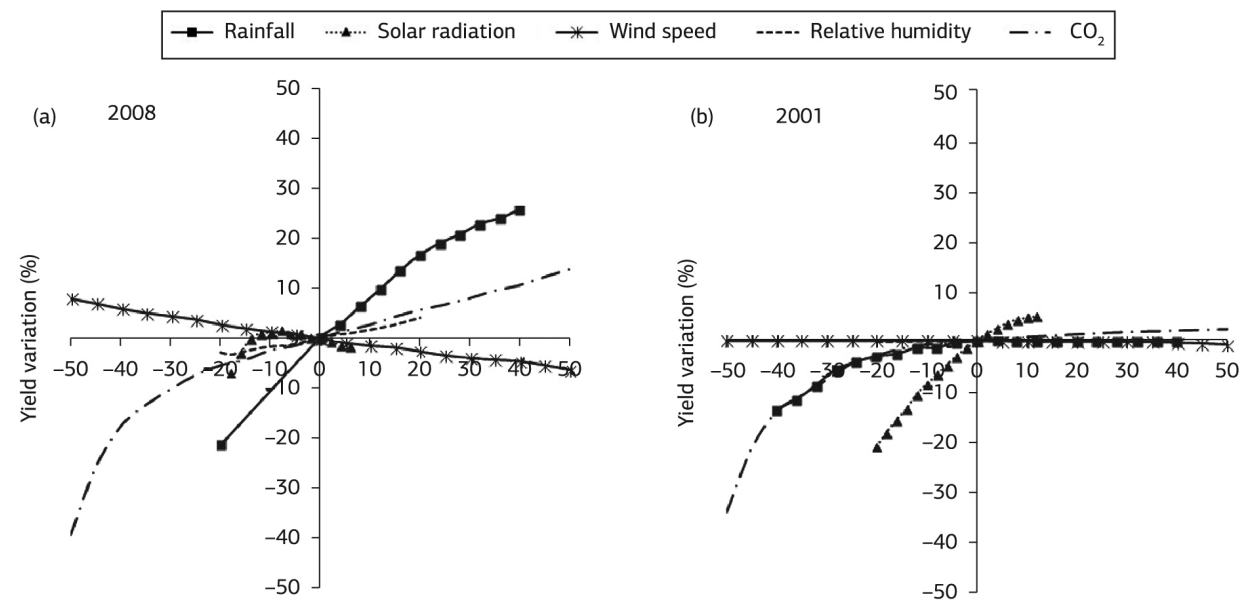

Variation of climatic variables (\%)

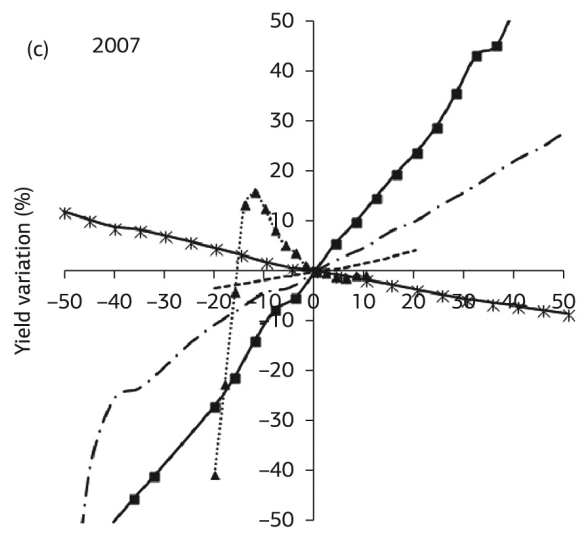

Variation of climatic variables (\%)

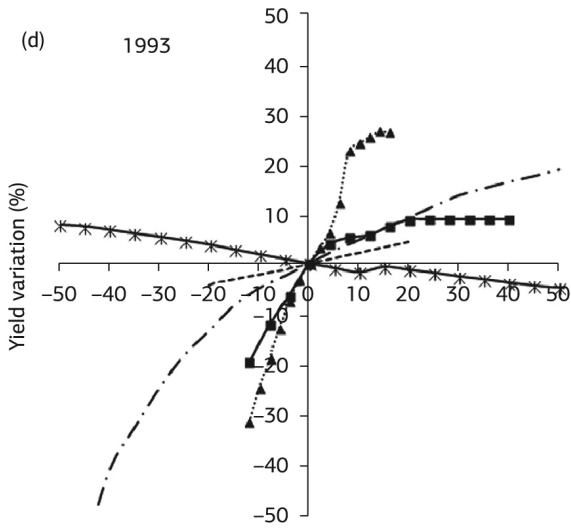

Variation of climatic variables (\%)

Figure 3. Sensitivity analyses of sorghum yields due to changes in meteorological variables. (a) Years 2007, (b) 1993, (c) 2008 and (d) 2001.

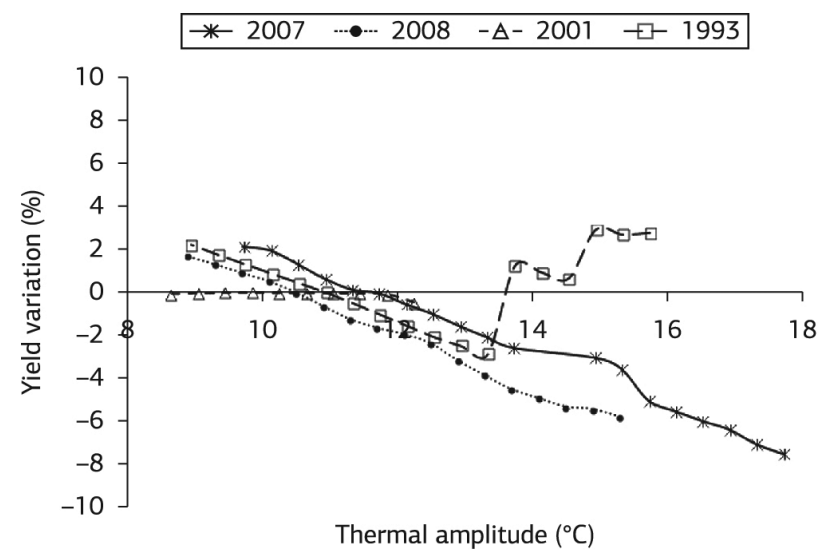

Figure 4. Response of the sorghum yield to changes in the thermal amplitude.

development in 2001 and 1993 presented here. However, it is beyond the scope of this paper to provide a detailed evaluation of the link between the thermal amplitude and the water stress.

\section{Simulated yield variability for present and future conditions based on GCMs}

The seasonal tool of DSSAT is also used to analyze the weather dependence of the sorghum yield. It has been chosen sowing dates in which the productivity of sorghum was maxima (Table 4). Based on observed data (INMET) the optimal sowing dated was November 14. When simulated based on GCMs the best sowing dates were shifted forward in the season. For the ECHAM, the best date occurs in December while for CCCma and GFDL the sowing windows move to January. According to Grossi et al. (2013) differences between the INMET and the GCMs are due to changes in the simulated rainfall. It has also been observed that with the exception of the GFDL, the date of maximum productivity occurs later in the future (Table 5).

Analyzing the distributions of productivities for the INMET and GCMs, considerable differences were observed (Figure 5). Indeed, under present day conditions yields simulated by DSSAT forced with GFDL and CCCma data were lower as compared to the INMET, while ECHAM yields are higher. Yields simulated with the CCCma data as compared to the INMET delivers differences in the median by up to $1500 \mathrm{~kg} \mathrm{ha}^{-1}$. The ECHAM, on the other 
Table 5. Climate series and date of sowing

\begin{tabular}{|c|c|c|c|c|c|c|c|}
\hline \multirow{2}{*}{ Timeseries } & \multirow{2}{*}{ INMET } & \multicolumn{2}{|c|}{ CCCma } & \multicolumn{2}{|c|}{ ECHAM } & \multicolumn{2}{|c|}{ GFDL } \\
\hline & & Pres. & Fut. & Pres. & Fut. & Pres. & Fut. \\
\hline Period & 1982-2009 & 1982-1999 & 2047-2064 & 1982-1999 & 2047-2064 & 1982-1999 & 2047-2064 \\
\hline Date of sowing & $14 \mathrm{Nov}$ & 9 Jan & 23 Jan & $12 \mathrm{Dec}$ & 2 Jan & 23 Jan & 2 Jan \\
\hline
\end{tabular}

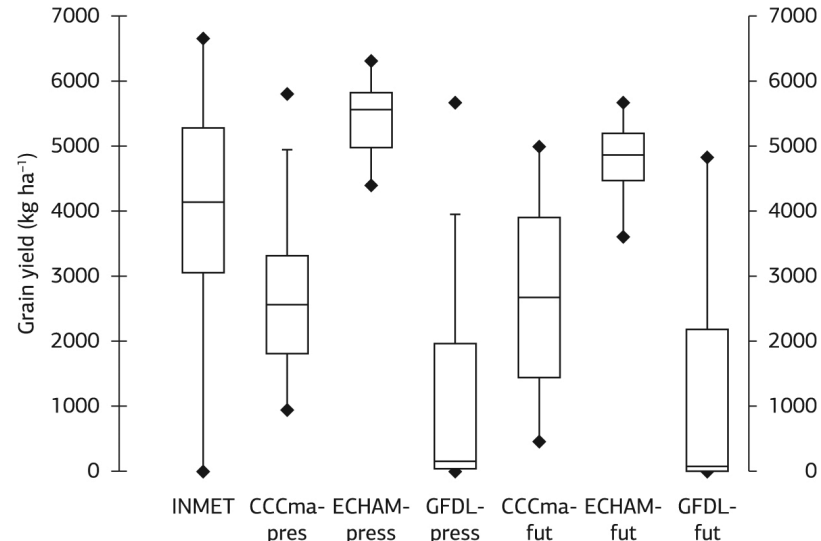

Figure 5. Simulated sorghum productivity based on INMET and GCMs for present (pres) and future (fut) intervals. In this Figure, and all the other box plots, exterior lines represent the maximum and minimum values (non-discrepant values); the outer points represent the discrepant maximum and minimum values; the upper and lower lines of the box represent, respectively, the upper quartile $(75 \%)$ and the lower quartile $(25 \%)$, while the center line represents the median $(50 \%)$.

hand provided the highest yield with the lowest amplitude (Figure 5).

Comparison between the present and the future period, shows a slight decrease in productivity based on ECHAM model for the 2047 to 2062 interval (Figure 5). For the other GCMs, a small difference between the medians were observed but with an increased variability of the sorghum productivity for future period.

Simulated yields are affected by the accumulated rainfall as well as by the daily variability during the crop cycle (Figure 6a). For the 1982-1999 period, the ECHAM simulated $575 \mathrm{~mm}$ cycle $^{-1}$ of rainfall and productivity of $5561 \mathrm{~kg} \mathrm{ha}^{-1}$. The GFDL model, simulated precipitation by about $92 \mathrm{~mm} \mathrm{cycle}^{-1}$ and the lowest yield $142 \mathrm{~kg} \mathrm{ha}^{-1}$. This is in agreement with the sensitivity analyses previously performed, showing that the water resource is the major constrain to overcome lower sorghum yield. Reduced productivity of sorghum for the future interval is also predicted to occur by the ECHAM model as compared to PD conditions, due to lower rainfall estimates. However, this was not observed with the CCCma, in which reduced precipitation did not lead to lower yields because other climate variables compensate reduced precipitation.

When mean conditions are evaluated, observed (INMET) values of radiation were similar to those simulated by the
GCMs (Figure 6b), but they exhibit distinct inter-annual variability. The GFDL model results demonstrated that for the present period in more than $25 \%$ of the years the accumulated radiation along the sorghum cycle was below the critical value of $1900 \mathrm{MJ} \mathrm{m}^{-2}$. This very likely reduces productivity in some years (Figure 6b). Regarding to the future period, a sharp drop in radiation for all GCMs are observed that potentially may affect the productivity. It should be mentioned that reduced productivity was only observed if DSSAT is driven with the ECHAM model output.

In terms of temperature it was observed that all GCMs are colder as compared to the INMET observations. The observed averaged temperature was $26.1{ }^{\circ} \mathrm{C}$, which was approximately $2{ }^{\circ} \mathrm{C}$ higher than the $24.4{ }^{\circ} \mathrm{C}, 23.8^{\circ} \mathrm{C}$ and $24.4^{\circ} \mathrm{C}$ simulated by the CCCma, ECHAM and GFDL, respectively (Figure $5 \mathrm{c}$ ). The lowest average temperature predicted by the ECHAM is another factor that may be related to the higher sorghum yields, as compared to the other models and observations.

The implementation of future climate conditions leads to higher temperature with respect to $\mathrm{PD}$, by $2.3^{\circ} \mathrm{C}$ for CCCma and ECHAM and by $2.7^{\circ} \mathrm{C}$ for the GFDL. This led to shorter sorghum cycle under future climate conditions (not shown). Moreover, reduced precipitation and radiation amounts, which were simulated by all models do not favor future sorghum yields. The temperature amplitude (bellow $8{ }^{\circ} \mathrm{C}$ ) simulated by the ECHAM for both present and future periods, is substantially lower as compared with the other GCMs (Figure 6d). According to the sensitivity analyses (Figure 7), the individual effect of lower temperature amplitude resulted in higher simulated productivity.

In general the GCMs overestimated the wind speed as compared to observed data (INMET). As discussed in the sensitivity analyses, wind speed and relative humidity are variables that indirectly affect productivity through the soil-water availability/evapotranspiration. Figures $6 e, f$ show that the sorghum yield benefited by these two variables, insofar the ECHAM input data is concerned with weaker wind speed and higher relative humidity in comparison with other models. As for the GFDL model, the lowest relative humidity values were simulated for both present and future periods that led to the lowest simulated yields. Sensitivity analysis to investigate the effect of $\mathrm{CO}_{2}$ (not shown) revealed that under optimum water conditions (no stress), the effect of increased $\mathrm{CO}_{2}$ is negligible whereas under 

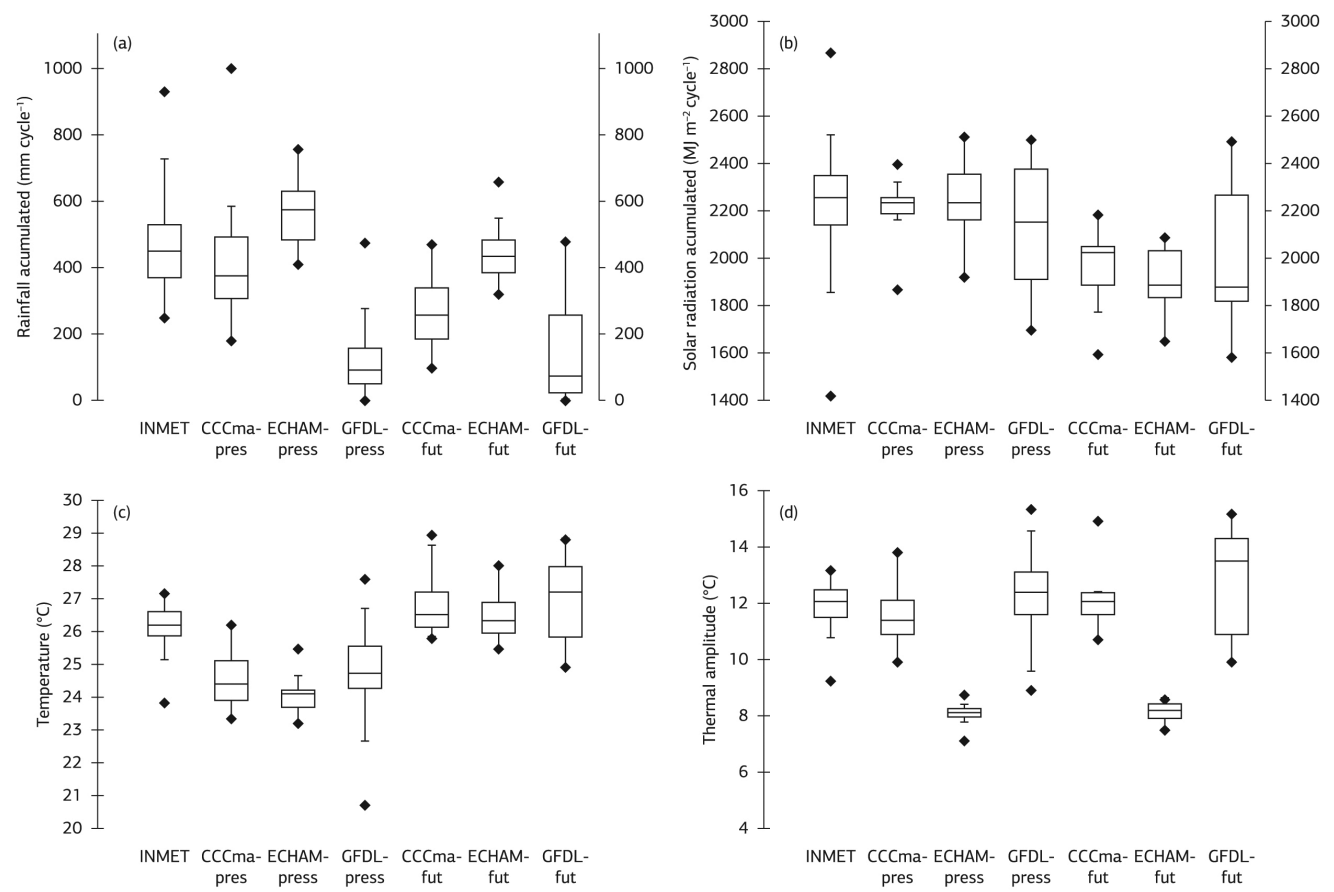

INMET CCCMa- ECHAM- GFDL- CCCMa- ECHAM- GFDL-
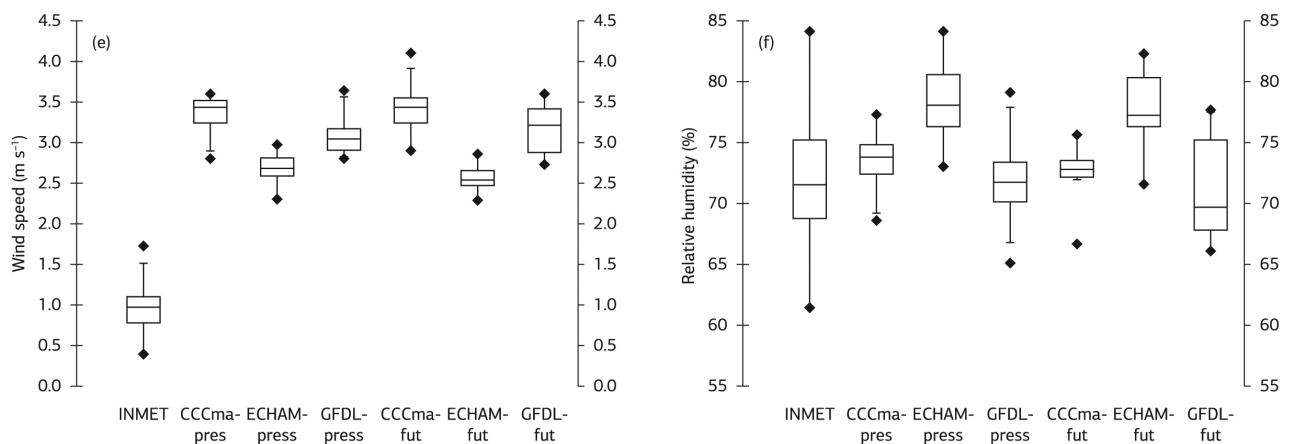

Figure 6. Simulated present day and future values of rainfall (a), solar radiation (b), temperature (c), thermal amplitude (d), wind speed (e) and relative humidity (f).

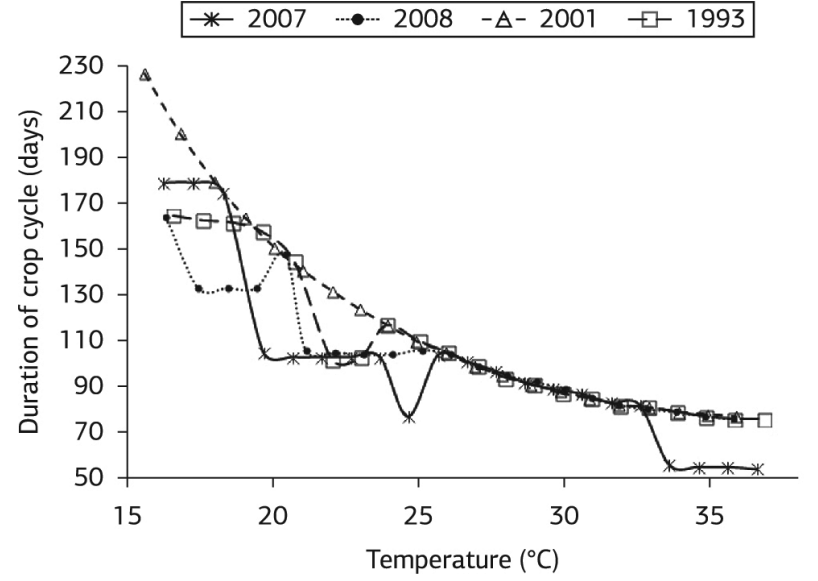

Figure 7. Response of the sorghum cycle length to changes in temperature.

water stress conditions it has a positive effect increasing the productivity.

This gives a broad range of possibilities in estimating the response of agriculture to climate variability and change.
This limitation can be partially alleviated by using outputs of different GCMs to figure out the most suitable climate model for a specific region.

\section{CONCLUSION}

Based on sensitivity analyses we demonstrated that:

The sensitivity of the sorghum productivity to climate variables varied from year to year and is tightly dependent on water availability.

The sorghum yield is more sensitive to rainfall, solar radiation and $\mathrm{CO}_{2}$ concentration. The increase in $\mathrm{CO}_{2}$ concentration has a positive (marginal) effect on yield in years that the crop has (has not) been submitted to water stress.

Accumulated solar radiation along the sorghum cycle below $1900 \mathrm{MJ} \mathrm{m}^{-2}$ reduces the yield.

The sorghum yield is less sensitive to changes in relative humidity and wind speed as compared to other weather elements. 


\section{ACKNOWLEDGEMENTS}

Research support has been provided through the collaboration between UFV and Norway Research Council through the CIXPAG project.

\section{REFERENCES}

Alagarswamy, G., Ritchie, J. T., Godwin, D. C., \& Singh, U. (1988). A user's guide to CERES sorghum (p. 1-91). Hawai: Michigan State University, ICRISAT, IFDC e IBSNAT.

Allen, R. G., Pereira, L. S., Raes, D., \& Smith, M. (1998). Crop evapotranspiration: guidelines for computing crop water requirements. Rome, Italy: Food and Agriculture Organization of the United Nations - FAO. 281 p.

Carbone, G. J., Kiechle, W., Locke, C., Mearns, L. O., McDaniel, L., \& Downton, M. (2003). Response of soybean and sorghum to varying spatial scales of climate change scenarios in the southeastern United States. Climatic Change, 60, 73-98. http://dx.doi. org/10.1023/A:1026041330889.

Chipanshi, A. C., Chanda, R., \& Totolo, O. (2003). Vulnerability assessment of the maize and sorghum crops to climate change in Botswana. Climatic Change, 61, 339-360.

Conley, M. M., Kimball, B. A., Brooks, T. J., Pinter, P. J., Jr., Hunsaker, D. J., Wall, G. W., Adam, N. R., Lamorte, R. L., Matthias, A. D., Thompson, T. L., Leavitt, S. W., Ottman, M. J., Cousins, A. B., \& Triggs, J. M. (2001). CO2 enrichment increases water use efficiency in sorghum. The New Phytologist, 151, 407-412. http://dx.doi. org/10.1046/j.1469-8137.2001.00184.x.

Costa, L. C., Justino, F., Oliveira, L. J. C., Sediyama, G. C., Ferreira, W.P. M., \& Lemos, C. F. (2009). Potential forcing of CO2, technology and climate changes in maize (Zea mays) and bean (Phaseolus vulgaris) yield in southeast Brasil. Environmental Research Letters, 4, 1-11. http://dx.doi.org/10.1088/1748-9326/4/1/014013.

Delworth, T. L., Broccoli, A. J., Rosati, A., Stouffer, R. J., Balaji, V., Beesley, J. A., Cooke, W. F., Dixon, K. W., Dunne, J., Dunne, K. A., Durachta, J. W., Findell, K. L., Ginoux, P., Gnanadesikan, A., Gordon, C. T., Griffies, S. M., Gudgel, R., Harrison, M. J., Held, I. M., Hemler, R. S., Horowitz, L. W., Klein, S. A., Knutson, T. R., Kushner, P. J., Langenhorst, A. R., Lee, H. C., Lin, S. J., Lu, J., Malyshev, S. L., Milly, P. C. D., Ramaswamy, V., Russell, J., Schwarzkopf, M. D., Shevliakova, E., Sirutis, J. J., Spelman, M. J., Stern, W. F., Winton, M., Wittenberg, A. T., Wyman, B., Zeng, F., \& Zhang, R. (2006). GFDL's CM2 Global Coupled Climate Models. Part I: Formulation and simulation characteristics. Journal of Climate, 19, 643-674. http://dx.doi.org/10.1175/JCLI3629.1.

Flato, G. M., \& Boer, G. J. (2001). Warming asymmetry in climate change simulations. Geophysical Research Letters, 28, 195-198. http://dx.doi.org/10.1029/2000GL012121.
Flato, G. M., \& Hibler, W. D. (1992). Modelling pack ice as a cavitating fluid. Journal of Physical Oceanography, 22, 626-651. http://dx.doi. org/10.1175/1520-0485(1992)022<0626:MPIAAC>2.0.CO;2.

Grossi, M. C., Justino, F., Andrade, C. L. T., Santos, E. A., Rodrigues, R. A., \& Costa, L. C. (2013). Modeling the impact of global warming on the sorghum sowing window in distinct climates in Brazil. European Journal of Agronomy, 51, 53-64. http://dx.doi. org/10.1016/j.eja.2013.07.002.

Jones, J. W., Hoogenboom, G., Porter, C. H., Boote, K. J., Batchelor, W. D., Hunt, L. A., Wilkens, P. W., Singh, U., Gijsman, A. J., \& Ritchie, J. T. (2003). The DSSAT cropping system model. European Journal of Agronomy, 18, 235-265. http://dx.doi.org/10.1016/ S1161-0301(02)00107-7.

Jungclaus, J. H., Keenlyside, N., Botzet, M., Haak, H., Luo, J. J., Latif, M., Marotzke, J., Mikolajewicz, U., \& Roeckner, E. (2006). Ocean circulation and tropical variability in the coupled model ECHAM5/MPI-OM. Journal of Climate, 19, 3952-3972. http:// dx.doi.org/10.1175/JCLI3827.1.

Kim, S. J., Flato, G. M., Boer, G. J., \& Mcfarlane, N. A. (2002). A coupled climate model simulation of the Last Glacial Maximum, Part 1: transient multi-decadal response. Climate Dynamics, 19, 515-537. http://dx.doi.org/10.1007/s00382-002-0243-y.

Kim, S. J., Flato, G. M., \& Boer, G. J. (2003). A coupled climate model simulation of the Last Glacial Maximum, Part 2: approach to equilibrium. Climate Dynamics, 20, 635-661. http://dx.doi. org/10.1007/s00382-002-0292-2.

Matthews, R., Stephens, W., Hess, T., Mason, T., \& Graves, A. (2000). Applications of crop/soil simulation models in developing countries. United Kingdom: Institute of Water and Environment, Cranfield University. 175 p.

Nakicenovic, N., Alcamo, J., Davis, G., Vries, B., Fenhann, J., Gaffin, S., Gregory, K., Grübler, A., Jung, T. Y., Kram, T., Rovere, E. L., Michaelis, L., Mori, S., Morita, T., Pepper, W., Pitcher, H., Price, L., Riahi, K., Roehrl, A., Rogner, H. H., Sankovski, A., Schlesinger, M., Shukla, P., Smith, S., Swart, R., Rooijen, S., Victor, N., \& Dadi, Z. (2000). Special report on emissions scenarios. Special report of Working Group III of the Intergovernmental Panel on Climate Change. Cambridge: Cambridge University Press. 599 p.

Saltelli, A., Chan, K., \& Scott, M. (Eds.). (2004). Sensitivity analysis. New York: John Wiley and Sons. 504 p.

Srivastava, A., Kumar, S. N., \& Aggarwal, P. K. (2010). Assessment on vulnerability of sorghum to climate change in India. Agriculture, Ecosystem \& Environment, 138, 160-169. http://dx.doi.org/10.1016/j. agee.2010.04.012.

Teixeira, A. H. C., \& Bassoi, L. (2009). Crop water productivity in semi-arid regions: from field to large scales. Annals of Arid Zone, $48,1-13$.

Tubiello, F. N., Donatelli, M., Rosenzweig, C., \& Stockle, C. O. (2000). Effects of climate change and elevated $\mathrm{CO} 2$ on cropping systems: model predictions at two Italian locations. European Journal of Agronomy, 13, 179-189. http://dx.doi.org/10.1016/S1161-0301(00)00073-3. 